\title{
KETERAMPILAN PENGOLAHAN MIE SEHAT DARI SAYUR SAWI UNTUK MENINGKATKAN GIZI DAN IMUNITAS TUBUH DI DESA SEI ASAM KELURAHAN SEI PASA KABUPATEN KAPUAS KALIMANTAN TENGAH
}

\author{
Processing Skill of Healthy Noodle from Mustard Green for Improving Nutrition and \\ Immunity in Sei Asam Village Sei Pasa Distrcit Kapuas Regency Central Kalimantan
}

\author{
${ }^{\star 1}$ Adelgrit Trisia, ${ }^{2}$ Indria Augustina, \& ${ }^{3}$ Dian Mutia \\ ${ }^{1}$ Department of Histology, Faculty of Medicine, Universitas Palangka Raya, Palangka Raya, Indonesia \\ ${ }^{2}$ Department of Parasitology, Faculty of Medicine, Universitas Palangka Raya, Palangka Raya, Indonesia \\ ${ }^{3}$ Department of Medical Science Community, Faculty of Medicine, Universitas Palangka Raya, Palangka Raya, \\ Indonesia \\ *e-mail : adelgrit trisia@yahoo.com
}

\begin{abstract}
ABSTRAK
Mie merupakan produk makanan yang sagat popular dan banyak dikonsumsi oleh masyarakat Indonesia. Dunia perdagangan mengenal mie dalam berbagai macam produk, Karena bahan baku utamanya adalah tepung terigu, tepung tapioka atau tepung beras, maka kandungan nutrisi yang terbesar pada mie dan produk olahannya adalah karbohidrat. Makanan yang dikonsumsi dengan kandungan gizi yang tidak seimbang, yaitu tinggi lemak/minyak, tinggi karbohidrat, tinggi garam, dan rendah serat. Dampak yang terjadi dengan makanan dengan gizi yang tidak seimbang, untuk jangka panjang adalah munculnya penyakit degeneratif seperti diabetes, penyakit kardiovaskuler seperti jantung dan hipertensi, serta kanker kolon, usus, dan lain - lain. Tujuan utama meningkatkan pengetahuan dan pemahaman bagi warga desa Sei Asem mengenai pengolahan mie sehat berbahan dasar sayur. Tujuan khususnya Membantu meningkatkan pengetahuan warga desa mengolah mie sehat berbahan sayur. Berupaya meningkatkan kesadaran warga desa mengenai pentingnya mengolah makanan berbahan dasar sehat kehidupan rumah tangga. Berupaya untuk mengingkatkan status kesehatan masyarakat dilingkungan desa Sei Asam. Metode Pelaksanaan kegiatan Program Kemitraan Masyarakat ini dengan cara penyuluhan, pelatihan dan pembimbingan. Hasil yang diperoleh dari kegiatan ini adalah meningkatnya pengetahuan penduduk desa mengenai manfaat sayur sawi, pengolahan sayur sawi menjadi mie dan salah satu upaya meningkatkan konsumsi gizi seimbang yang dapat meningkatkan daya tahan tubuh atau imunitas.
\end{abstract}

Kata kunci: Mie, Sayur, Imunitas

\begin{abstract}
Noodle is a popular food product and widely consumed by the people in Indonesia. The world of commerce knows noodles in a variety of products, Because the main ingredients are wheat flour, tapioca flour or rice flour, then the greatest nutritional content in noodles and processed products is carbohydrates. Foods consumed with unbalanced nutritional content, which are high in fat / oil, high carbohydrate, high salt, and low in fiber. The impact that occurs with food with unbalanced nutrition, for the long term is the emergence of degenerative diseases such as diabetes, cardiovascular diseases such as heart and hypertension, and cancer and others. The main objective is to increase knowledge and understanding for the villagers of Sei Asem regarding the processing of healthy noodles based on vegetables. Specific Objectives To help improve the knowledge of villagers to process healthy noodles made from vegetables. Attempts to raise awareness of the villagers about the importance of processing food based on healthy life of the household. Attempts to improve the health status of the community in the village of Sei Asam Method of Implementation of Community Partnership Program activities by way of counseling, training and mentoring. The results obtained from this activity is the increasing knowledge of the villagers about the benefits of Sawi vegetable, processing of sawi vegetables into noodles and one of the efforts to increase the consumption of balanced nutrition that can increase immunity.
\end{abstract}

Keywords: Noodle, Vegetable, Immunity 


\section{PENDAHULUAN}

Mie merupakan produk makanan yang sagat popular dan banyak dikonsumsi oleh masyarakat Indonesia. Dunia perdagangan mengenal mie dalam berbagai macam produk, seperti mie basah, mie kering, mie soun dan mie bihun. Masingmasing jenis mie ini berbeda dalam bahan baku dan sistem pengolahannya. Mie basah dan mie kering terbuat dari bahan baku tepung terigu, yang membedakan antara keduanya adalah di akhir prosesnya, pada mie kering dilakukan tahap pengeringan produk sebelum dipasarkan, sedangkan mie basah tidak. Ada beberapa kelebihan mie dibandingkan dengan bahan pangan utama lainnya, antara lain adalah rasanya yang khas dan terutama adalah karena produk mie sering dikemas dalam bentuk yang praktis. Meskipun ada keunggulan dari mie tetapi nilai kandungan gizi pada produk mie ini masih sangat rendah, terutama kandungan proteinnya. Karena bahan baku utamanya adalah tepung terigu, tepung tapioka atau tepung beras, maka kandungan nutrisi yang terbesar pada mie dan produk olahannya adalah karbohidrat (Ratnasari \& Wirawanni, 2012; Arianto, 2013).

Sayuran merupakan komoditas penting dalam mendukung ketahanan pangan nasional. Komoditas ini memiliki keragaman yang luas dan berperan sebagai sumber karbohidrat, protein nabati, vitamin, dan mineral yang bernilai ekonomi tinggi. Produksi sayuran Indonesia meningkat setiap tahun dan konsumsinya tercatat 44 $\mathrm{kg} / \mathrm{kapita/tahun.} \mathrm{Laju} \mathrm{pertumbuhan} \mathrm{produksi}$ sayuran di Indonesia berkisar antara 7,7-24,2\% per tahun. Beberapa jenis sayuran, seperti bawang merah, sawi, dan mentimun peningkatan produksinya merupakan dampak dari penerapan teknologi budidaya. Sawi merupakan jenis sayur yang digemari oleh masyarakat Indonesia dengan konsumennya dari berbagai macam golongan masyarakat kelas bawah hingga golongan masyarakat kelas atas. Kelebihan lainnya sawi mampu tumbuh baik di dataran rendah maupun dataran tinggi (Nurshanti, 2010).

Salah satu cara yang efektif dalam mencegah penyakit adalah melalui peningkatan gizi di masyarakat. Pemberian makanan bergizi dapat meningkatkan kekebalan (Imunitas) seseorang terhadap suatu penyakit. Makanan yang popular dikalangan masyarakat dan disukai oleh anak anak adalah mie. Mie merupakan produk olahan pabrik dengan proses pengolahan dengan bahan - bahan dengan standar pabrik. Pelatihan pengolahan mie sehat berbahan dasar sayur ini diharapkan dapat meningkatkan komposisi nilai gizi dengan penambahan bahan dan proses pembuatan yang lebih alami. Peningkatan nilai gizi yang diperoleh dari mie berbahan dasar sayur sawi dapat memberikan asupan nutrisi yang bergizi sehingga meningkatkan imunitas tubuh (Roitt, 2002; Baratawidjaja, 2004).

\section{METODOLOGI}

Metode yang digunakan dalam penelitian ini adalah sebagai berikut:

1. Penyuluhan, pelatihan dan pembimbingan praktik mengolah mie sehat berbahan dasar sayur sawi

2. Pelaporan dan presentasi hasil kegiatan

3. Evaluasi hasil kegiatan agar diketahui manfaat dan kekurangan dari pelaksanaan kegiatan. 


\section{HASIL DAN PEMBAHASAN}

Pelaksanaan kegiatan Program Kemitraan Masyarakat di desa Sei Asam, Kelurahan Sei Pasah, Kabupaten Kapuas, Kalimantan Tengah dengan tujuan utama meningkatkan pengetahuan dan pemahaman bagi warga desa Sei Asem mengenai pengolahan mie sehat berbahan dasar sayur. Tujuan khususnya Membantu meningkatkan pengetahuan warga desa mengolah mie sehat berbahan sayur. Berupaya meningkatkan kesadaran warga desa mengenai pentingnya mengolah makanan berbahan dasar sehat kehidupan rumah tangga. Berupaya untuk mengingkatkan status kesehatan masyarakat dilingkungan desa Sei Asam.

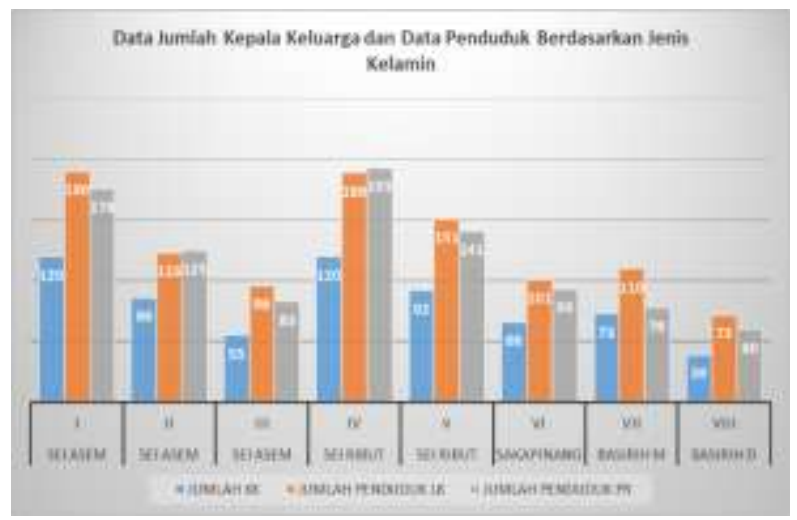

Gambar 1 Data Jumlah Kepala Keluarga dan Data Penduduk Berdasarkan Jenis Kelamin

Berdasarkan gambar 1 Data Kecamatan Kapuas Hilir pada tahun 2015, memiliki beberapa desa dan setiap desa memiliki rukun tetangga/ RT. Desa Sei Asem menempati RT I, II dan III. Dari data tersebut desa Sei Asem memiliki jumlah kepala kelurga di desa Sei Asem sebesar 261 kepala keluarga dengan jumlah penduduk berjenis kelamin laki laki lebih banyak dari jumlah penduduk berjenis kelamin perempuan sebesar $51,6 \%$ dari jumlah total penduduk di Sei Asem.

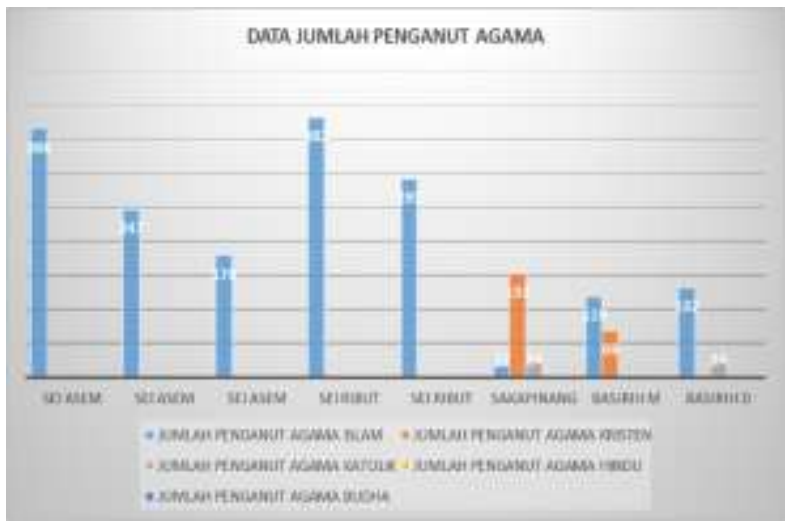

Gambar 2 Data Jumlah Penganut Agama

Berdasarkan gambar 2 Data Kecamatan Kapuas Hilir pada tahun 2015, jumlah penganut agama islam menmpati angka tertinggi di desa sei Asem dengan jumlah 792 orang. Diikuti dengan Jumlah penganut agama Katolik dan Kristen pada desa Sakapinang dan Basirih

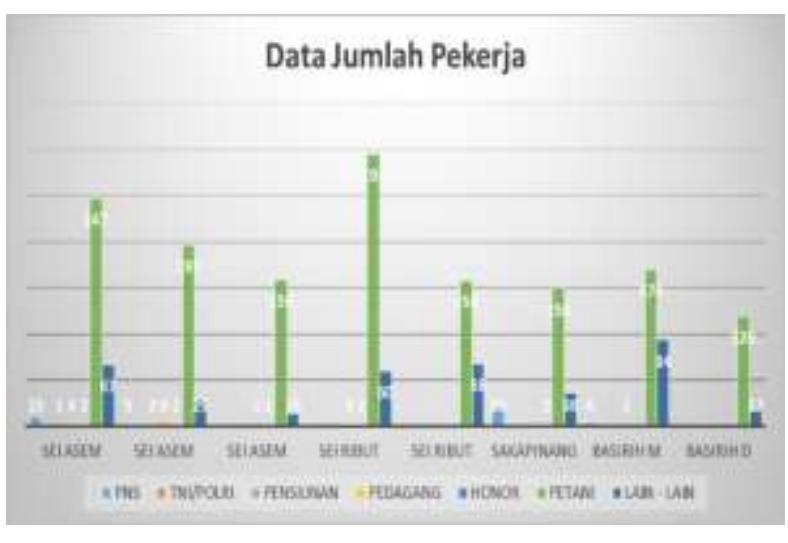

Gambar 3 Data Jumlah Pekerja

Berdasarkan gambar 3 Data Kecamatan Kapuas Hilir pada tahun 2015, data jumlah pekerja terbanya adalah petani. Desa sei Asem seperti diketahui lokasinya berada di pinggir sungai dan mata pencaharian yang dilakukan penduduk adalah bertani. Dengan jumlah di Desa Sei Asem sebanyak 603 orang. Pekerjaan lainnya yaitu pedagang sebanyak 11 orang, tenaga honor sebesar 5 orang, dan lain - lain sebesar 110 orang. 
Tabel 1 Hasil Kegiatan dan uraian Kondisi sebelum dan sesudah kegiatan Program Kemitraan Masyarakat

\begin{tabular}{|c|c|c|}
\hline Uraian & $\begin{array}{l}\text { Kondisi sebelum kegiatan } \\
\text { Program Kemitraan } \\
\text { Masyarakat }\end{array}$ & $\begin{array}{c}\text { Kondisi setelah kegiatan } \\
\text { Program Kemitraan Masyarakat }\end{array}$ \\
\hline $\begin{array}{l}\text { Pengetahuan Manfaat, } \\
\text { Kandungan gizi dan } \\
\text { Pengolahan sayur Sawi }\end{array}$ & $\begin{array}{l}\text { Peserta pelatihan belum } \\
\text { mengetahui manfaat dan } \\
\text { kandungan gizi dari sayur } \\
\text { sawi }\end{array}$ & $\begin{array}{l}\text { Mengetahui manfaat, kandungan } \\
\text { gizi dan cara pengolahan sayur } \\
\text { sawi. Dengan pengolahan sayur } \\
\text { sawi yang benar dapat } \\
\text { meningkatkan kandungan gizi } \\
\text { dalam pangan makanan dan } \\
\text { dapat meningkatkan daya tahan } \\
\text { atau imunitas tubuh dengan } \\
\text { memberikan asupan makanan } \\
\text { yang bergizi }\end{array}$ \\
\hline $\begin{array}{l}\text { Ketrampilan pengolahan } \\
\text { produk sayuran }\end{array}$ & $\begin{array}{l}\text { Penduduk desa hanya } \\
\text { mengolah sayuran dimasak } \\
\text { menjadi sayur mayur untuk } \\
\text { di konsumsi recara } \\
\text { langsung }\end{array}$ & $\begin{array}{l}\text { Penduduk desa memiliki } \\
\text { ketrampilan untuk mengolah } \\
\text { sayur menjadi mie sayur sawi }\end{array}$ \\
\hline $\begin{array}{l}\text { Peningkatan nilai ekonomi } \\
\text { sayuran }\end{array}$ & $\begin{array}{l}\text { Penduduk desa memiliki } \\
\text { pekerjaan petani, sebagian } \\
\text { menanam sayur tetapi } \\
\text { dijual dengan nilai yang } \\
\text { relative murah }\end{array}$ & $\begin{array}{l}\text { Penduduk desa telah diberi } \\
\text { pengetahuan dan ketrampilan } \\
\text { untuk meningkatkan nilai } \\
\text { eknomis produk olahan mie } \\
\text { sayur }\end{array}$ \\
\hline $\begin{array}{l}\text { Potensi pengembangan } \\
\text { ekonomi }\end{array}$ & \begin{tabular}{lr} 
Penduduk desa & belum \\
mengetahui & potensi \\
peningkatan & dan \\
pengembangan & ekonomi \\
\multicolumn{2}{l}{ dari produk sayuran }
\end{tabular} & $\begin{array}{l}\text { Penduduk desa lebih terbuka } \\
\text { wawasannya untuk } \\
\text { pengembangan potensi ekonomi } \\
\text { dari produk olahan sayuran. } \\
\text { walaupun belum ada modal } \\
\text { untuk mengembangkan menjadi } \\
\text { produk yang dijual dan jenis lain. } \\
\text { dengan pelatih memberikan } \\
\text { kesempatan untuk pembinaan } \\
\text { kearah produk selain mie sayur. } \\
\text { dan perencanaan pengembangan } \\
\text { pertanian di desa Sei Asem }\end{array}$ \\
\hline
\end{tabular}

Keterampilan untuk memanfaatkan sayuran menjadi produk-produk olahan yang bernilai secara ekonomis, higienis dan kualitas gizi yang tinggi dan berimbang, sangat penting untuk dilatihkan kepada penduduk di desa Sei Asem. Pelatihan tersebut meliputi:

1. Tahap I. Persiapan pelatihan Keterampilan Pengolahan Mie Sehat Dari Sayur Sawi

2. Tahap II. Tahap pelatihan Keterampilan Pengolahan Mie Sehat Dari Sayur Sawi

3. Tahap III. Tahap pendampingan dan monitoring pengembangan Keterampilan Pengolahan Mie Sehat Dari Sayur Sawi
4. Tahap IV. Tahap evaluasi pelaksanaan kegiatan Keterampilan Pengolahan Mie Sehat Dari Sayur Sawi

Pelaksanaan kegiatan Program Kemitraan Masyarakat di desa Sei Asam, Kelurahan Sei Pasah, Kabupaten Kapuas, Kalimantan Tengah memiliki kendala yakni:

1. Semangat untuk memulai dan mengembangkan usaha berbasis produk olahan dari sayuran sangat tinggi dan di apresiasi baik oleh ibu - ibu PKK desa Sei Asem tetapi terkendala pada mahalnya biaya pembelian alat produksi dan tidak ada modal usaha untuk mengembangkannya menjadi suatu produk ketingkat komersil.

2. Penduduk desa mata pencahariannya adalah petani dengan tanaman padi sebagai komoditas utama yang di tanamn, sedangkan sayuran belum dikembangkan potensinya di Desa Sei Asem. Dengan pengembangan lahan khusus unutk sayuran dapat meningkatkan peluang untuk memperoleh bahan pokok pengolahan mie sehat tanpa membeli.

Evaluasi terhadap kendala dan hambatan ini, tentu menjadi hal yang sangat penting untuk di tindak lanjut pada pelaksanaan kegiatan berikutnya.

\section{KESIMPULAN}

Dari Pelaksanaan kegiatan Program Kemitraan Masyarakat di desa Sei Asam, Kelurahan Sei Pasah, Kabupaten Kapuas, Kalimantan Tengah telah diperoleh hasil sebagai berikut:

1. Terdapat peningkatan pengetahuan dan kesadaran mengenai pentingnya mengolah makanan mie dengan bahan dasar yang sehat dalam kehidupan rumah tangga 
2. Terdapat peningkatan motivasi warga desa dalam mengolah makanan mie dengan menggunakan bahan dasar yang sehat

3. Terdapat peningkatan usaha untuk hidup lebih memperhatikan kesehatan dan diharapkan dapat meningkatkan daya tahan tubuh atau imunitas.

\section{DAFTAR PUSTAKA}

Arianto NT. 2013. Pola Makan Mi Instan: Studi Antropologi Gizi Pada Mahasiswa. BioKultur, 2(1): 27-40.

Bahat BBS. 2014. BPS Kapuas. Kabupaten Kapuas.

Baratawidjaja GK, 2004. Imunologi Dasar. Edisi Keenam. Jakarta: Universitas Indonesia Press.

Handayani S. 2013. Tehnik Pembuatan Mie Sehat. Yogyakarta: UNY Press.

Muhtadi, Rauf R, Harismah K, Saifuddin. 2016. Pengembangan Produk Olahan Tepung Sayuran Di Desa Sindon Kecamatan Ngemplak Kabupaten Boyolali. Warta LPM, 19(1): 83-89.

Nurshanti DF. 2010. Pertumbuhan dan Produksi Tanaman Sawi (Brasicca juncea $L$ ) dengan Tiga Varietas Berbeda. AgronobiS, 2(4): 710.

Ratnasari DK, Wirawanni Y. 2012. Gambaran Kebiasaan Makan Mie Instan Pada Anak Usia 7 - 12 Tahun. Skripsi: Universitas Diponegoro.

Roitt, IM. 2002. Imunologi edisi delapan. Jakarta: Widya Medika. 